\title{
PENGARUH PERENCANAAN PAJAK, BEBAN PAJAK TANGGUHAN DAN KEBIJAKAN DIVIDEN TERHADAP MANAJEMEN LABA \\ (Studi Pada Perusahaan Manufaktur Sektor Consumer Good Industry Yang Terdaftar di Bursa Efek Indonesia)
}

\author{
Edon Ramdani $^{1}$, Aulya Ana Musdhalifah ${ }^{2}$ \\ Program Studi Sarjana Akuntansi Universitas Pamulang \\ edon_ramdani@yahoo.com, aulyaana4@gmail.com
}

\begin{abstract}
The purpose of this research is to determine and provide empirical evidence regarding the effect of tax planning, deferred tax expense and dividend policy on earnings management in consumer goods industry companies listed on the Indonesia Stock Exchange for the 2015-2019 period. The number of samples in this study were 12 companies obtained by using purposive sampling method based on predetermined criteria. The data used is secondary data in the form of an annual report for the period 2015 - 2019 taken from the www.idx.coid website. The data analysis technique used is descriptive statistical technique, panel data regression model, panel data regression model estimation, classical assumption test, coefficient of determination, $f$ test (as a simultaneous test) and test (as a partial test). The results of this study indicate that in a partial test, tax planning has no effect on earnings management, deferred tax expense affects earnings management and dividend policy has no effect on earnings management. While the results of the study simultaneously variable tax planning, deferred tax expense and dividend policy simultaneously affect earnings management.
\end{abstract}

Keywords:Tax Planning, Defered Tax Expense, Dividen Policy, Earnings Management

\section{PENDAHULUAN}

\section{Latar Belakang Penelitian}

Perusahaan dihadapkan dengan persaingan yang keras untuk dapat eksis dalam pasar global, khususnya untuk industri manufaktur di Indonesia. Dalam rangka untuk kuat bersaing, perusahaan dituntut untuk memiliki keunggulan kompetitif dari perusahaan lainnya. Perusahaan tidak hanya dituntut untuk menghasilkan produk yang bermutu bagi konsumennya, tetapi mampu mengelola keuangan dengan baik, artinya kebijkan pengelolaan keuangan harus dapat menjamin kelangsungan usaha perusahaan. Manajemen perusahaan bertanggung jawab dalam mengelola keuangan sesuai dengan prinsip - prinsip akuntabilitas.

Penyusunan laporan keuangan oleh manajemen bertujuan untuk menyampaikan informasi mengenai kondisi keuangan dan ekonomi perusahaan pada periode tertentu. Manajemen perusahaan terkadang memberikan sinyal positif kepada pasar tentang kondisi perusahaan yang dikelolanya. Oleh karena itu, manajer perusahaan kemudian berkeinginan untuk menaikkan laba yang dilaporkan kepada para pemegang saham dan pemakai eksternal lainnya. Situasi ini memungkinkan manajer untuk melakukan perilaku menyimpang dalam menyajikan dan melaporkan informasi laba tersebut yang dikenal dengan praktik manajemen laba (Astutik dan Titik, 2016 dalam Lubis dan Suryani, 2018).

Salah satu fenomena mengenai manajemen laba yang terjadi pada beberapa perusahaan besar. Contoh PT Tiga Pilar sejahtera Food Tbk (AISA) merupakan perusahaan yang bergerak di bidang produksi barang - barang consumer good. Fenomena ini bermula dari ditemukannya 
fakta bahwa direksi lama melakukan penggelembungan dana senilai $\mathrm{Rp} 4$ triliun, lalu ada juga temuan dugaan penggelembungan pendapatan senilai Rp 662 miliar dan penggelembungan lain senilai Rp 329 miliar pada pos EBITDA (laba sebelum bunga, pajak, depresiasi dan amortisasi) entitas bisnis makanan dari emiten tersebut. Temuan lain dari laporan investigasi Ernst \& Young Indonesia (EY) tersebut adalah aliran dana Rp 1,78 triliun melalui berbagai skema dari Grup AISA kepada pihak-pihak yang diduga terafiliasi dengan manajemen lama. "Antara lain menggunakan pencairan pinjaman Grup AISA dari beberapa bank, pencairan deposito berjangka, transfer dana di rekening bank, dan pembiayaan beban pihak terafiliasi oleh Grup AISA. https://www.cnbcindonesia.com. Dengan adanya penggelembungan pada pos pendapatan dan akuntansi, mengakibatkan upaya perusahaan merekayasa laporan keuangan dengan memanajemen laba atau melakukan pemerataan laba agar kondisi laporan keuangan terlihat stabil dengan tahun sebelumnya. Tujuannya, agar citra perusahaan tetap terlihat baik dan dapat menarik pihak investor. Karena investor akan tertarik pada laba perusahaan yang cenderung stabil setiap tahunnya.

Beberapa faktor yang mempengaruhi manajemen laba salah satunya adalah perencanaan pajak. Menurut Aditama dan Anna (2014) dalam Putra dkk (2019) Tax planning (perencanaan pajak) merupakan bagian manajemen pajak dan merupakan langkah awal di dalam melakukan manajemen pajak Perusahaan melakukan penghematan atau penundaan pajak (pajak tangguhan) melalui kecenderungan perusahaan untuk mengurangi laba yang dilaporkan. Penelitian pada perusahaan manufaktur yang terdaftar di Bursa Efek Indonesia periode 20152017 menyatakan bahwa variabel perencanaan pajak tidak berpengaruh secara signifikan terhadap manajemen laba. Achyani dan Lestari (2019). Sedangkan penelitian pada perusahaan manufaktur sub sektor makanan dan minuman yang terdaftar di Bursa Efek Indonesia periode 2013-2017 menyatakan bahwa variabel perencanaan pajak berpengaruh signifikan terhadap manajemen laba. Putra, Sunarta, dkk (2019)

Selain perencanaan pajak, faktor lain yang mempengaruhi manajemen laba yaitu beban pajak tangguhan. Beban pajak tangguhan merupakan beban yang timbul akibat perbedaan antara laba akuntansi (yaitu laba dalam laporan keuangan untuk kepentingan pihak eksternal) dengan laba fiskal (laba yang digunakan sebagai dasar perhitungan pajak) Harnanto, (2003:115) dalam Achyani (2019). Penelitian pada perusahaan industri barang konsumsi yang terdaftar di Bursa Efek Indonesia periode 2012-2016 menyatakan bahwa variabel beban pajak tangguhan tidak berpengaruh terhadap manajemen laba. Lubis dan Suryani (2018). Adapun penelitian pada perusahaan minyak bumi yang terdaftar di Bursa Efek Indonesia menyatakan bahwa variabel beban pajak tangguhan berpengaruh positif terhadap manajemen laba. Lestari (2018)

Faktor selanjutnya adalah kebijakan dividen, Kebijakan dividen menjadi salah satu motivasi manajemen laba dengan pola menurunkan laba. Kebijakan dividen adalah logis dikatakan sebagai motivasi manajer melakukan manajemen laba, karena kebijakan dividen ditentukan oleh rapat umum pemegang saham dan bukan merupakan keputusan manajemen sehingga kebijakan dividen menjadi sumber konflik kepentingan antara manajemen dan pemegang saham. Penelitian pada perusahaan manufaktur yang terdaftar di Bursa Efek Indonesia menyatakan bahwa variabel kebijakan dividen tidak berpengaruh terhadap manajemen laba. Wirawati, Putri, dkk (2018). Adapun penelitian pada perusahaan manufaktur yang terdaftar di Bursa Efek Indonesia periode 2012-2016 menyatakan bahwa variabel kebijakan dividen berpengaruh terhadap manajemen laba. Wijayanti (2018).

Peneliti termotivasi untuk melakukan penelitian terhadap manajemen laba karena terdapat ketidakkonsistensian pada hasil penelitian yang telah dilakukan oleh peneliti sebelumnya. Mengingat pentingnya penelitian manajemen laba, dan fenomena yang terjadi, maka peneliti tertarik untuk mengangkat kembali dan melakukan penelitian dengan judul "Pengaruh Perencanaan Pajak, Beban Pajak Tangguhan dan Kebijakan Dividen (Studi Pada Perusahaan Sektor Consumer Good industry Yang Terdaftar Di Bursa Efek Indonesia periode 2015 - 2019)". 


\section{Rumusan Masalah}

Berdasarkan latar belakang penelitian diatas, maka rumusan masalah dalam penelitian ini adalah sebagai berikut :

1. Apakah perencanaan pajak berpengaruh terhadap manajemen laba pada perusahaan sektor consumer good industry di Bursa Efek Indonesia?

2. Apakah beban pajak tangguhan berpengaruh terhadap manajemen laba pada perusahaan sektor consumer good industry di Bursa Efek Indonesia?

3. Apakah kebijakan dividen berpengaruh terhadap manajemen laba perusahaan sektor consumer good industry di Bursa Efek Indonesia?

4. Apakah perencanaan pajak, beban pajak tangguhan dan kebijakan dividen berpengaruh terhadap manajemen laba perusahaan sektor consumer good industry di Bursa Efek Indonesia?

\section{Tujuan Penelitian}

1. Untuk mengetahui pengaruh perencanaan pajak terhadap manajemen laba pada perusahaan sektor consumer good industry di Bursa Efek Indonesia.

2. Untuk mengetahui pengaruh beban pajak tangguhan terhadap manajemen laba perusahaan sektor consumer good industry di Bursa Efek Indonesia.

3. Untuk mengetahui pengaruh kebijakan dividen terhadap manajemen laba perusahaan sektor consumer good industry di Bursa Efek Indonesia.

4. Untuk mengetahui pengaruh perencanaan pajak, beban pajak tangguhan dan kebijakan dividen terhadap manajemen laba perusahaan sektor consumer good industry di Bursa Efek Indonesia.

\section{Manfaat Penelitian}

Hasil penelitian ini diharapkan mampu dijadikan bahan acuan bagi perusahaan, khususnya perusahaan manufaktur sektor konsumsi barang industri untuk merumuskan kebijakan serta tindakan-tindakan selanjutnya sehubungan dengan memaksimalkan manajemen laba perusahaan.

\section{TINJAUAN PUSTAKA}

\section{Teori Keagenan (Agency Theory)}

Dalam teori keagenan (Agency Theory) memiliki asumsi bahwa tiap - tiap individu semata- mata termotivasi oleh kepentingan dirinya sendiri sehingga menimbulkan konflik kepentingan antara principal dan agen (Suripto, 2021). Pemilik atau para pemegang saham mendelegasikan kewenangannya kepada manajemen untuk mengelola perusahaan. Pemilik diasumsikan hanya tertarik pada pengembalian keuangan yang diperoleh dari investasi mereka kepada perusahaan. Sedangkan manajemen diasumsikan akan menerima kepuasan tidak hanya dari kompensasi keuangan tetapi juga dari tambahan lain yang terlibat dalam hubungan keuangan. Sesuai dengan asumsi tersebut, maka manajer akan mengambil kebijakan yang menguntungkan dirinya sebelum memberikan manfaat kepada pemegang saham (Mettawidya, 2015) dalam Timuriana dan Muhammad, (2015).

\section{METODE}

\section{Jenis Penelitian}

Jenis penelitian yang digunakan dalam penelitian ini adalah penelitian kuantitatif dengan pendekatan deskriptif dan analisi verifikatif.

\section{Tempat Penelitian}

Penelitian ini dilakukan di Galeri Investasi Bursa Efek Indonesia (GIBEI) Fakultas Ekonomi Akuntansi Universitas Pamulang yang bekerja sama dengan PT Lotus Sekuritas dan internet searching di www.idx.co.id. 


\section{Populasi dan Sampel}

Teknik pengambilan sampel yang digunakan dalam penelitian ini adalah Purposive Sampling dengan tujuan untuk mendapatkan sampel yang sesuai dengan tujuan penelitian. Metode Purposive Sampling merupakan metode pengambilan sampel yang didasarkan pada beberapa pertimbangan atau kriteria tertentu. Kriteria perusahaan yang akan akan dijadikan sampel dalam penelitian ini adalah sebagai berikut:

1. Perusahaan manufaktur yang terdapat di Bursa Efek Indonesia pada tahun 2015-2019.

2. Perusahaan yang tidak mengalami delisting selama tahun 2015-2019

3. Perusahaan yang mengalami laba selama tahun 2015 - 2019

4. Perusahaan yang membagikan dividen selama tahun 2015 - 2019

Tabel 1

Perusahaan Manufaktur

\begin{tabular}{|l|l|l|}
\hline \multicolumn{1}{|c|}{ NO } & Kode Saham & \multicolumn{1}{c|}{ Nama Perusahaan } \\
\hline 1 & WIIM & Wismilak Inti Makmur Tbk \\
\hline 2 & DVLA & Darya-Varia Laboratoria Tbk \\
\hline 3 & KLBF & Kalbe Farma Tbk \\
\hline 4 & ICBP & Indofood CBP Sukses Makmur Tbk \\
\hline 5 & INDF & Indofood Sukses Makmur Tbk \\
\hline 6 & SIDO & Industri Jamu dan Farmasi Sido Muncul Tbk \\
\hline 7 & SKLT & Sekar Laut Tbk \\
\hline 8 & TSPC & Tempo Scan Pacific Tbk \\
\hline 9 & KINO & Kino Indonesia Tbk \\
\hline 10 & TCID & Mandom Indonesia Tbk \\
\hline 11 & UNVR & Unilever Indonesia Tbk \\
\hline 12 & CINT & Chitose Internasional Tbk \\
\hline
\end{tabular}

\section{Teknik Pengumpulan Data}

Pengumpulan data dilakukan dengan cara penelusuran data sekunder, yaitu dilakukan dengna kepustakaan dan manual. Metode yang digunakan adalah metode dokumentasi. Metode dokumentasi adalah mencari, mengumpulkan, mencatat dan mengkaji data mengenai hal-hal atau variable yang berupa catatan, dokumen, transkrip, buku, surat kabar, majalah, jurnal, situs, dan sebagainya. Metode dokumentasi dalam penelitian ini dilakukan dengan cara mengumpulkan data sekunder yang dipublikasikan dari Bursa Efek Indonesia (BEI)

\section{Manajemen Laba}

Variabel dependen dalam penelitian ini adalah manajemen laba, dalam penelitian ini diukur dengan mengukur discretionary accrual dengan menggunakan Modified Jones Model (Dechow et al., 1996 dalam Achyani dan Lestari, 2019) diproksi dengan discretionary accrual dan dihitung dengan modified jones model. Pengukuran discretionary accrual dilakukan dengan

\section{Langkah I}

Menghitung Total accruals perusahaan i pada periode t menggunakan rumus:

\section{TACit $=$ Nit - CFOit}

\section{Langkah II} berikut:

Nilai total accrual diestimasi dengan menggunakan regresi linear berganda sebagai

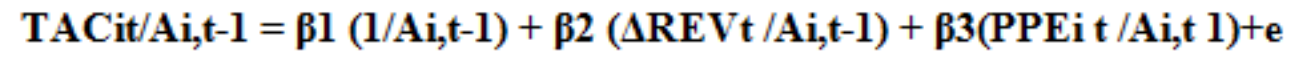

\section{Langkah III}


Dari persamaan regresi diatas, NDA (non discretionary) dapat dihitung dengan memasukkan kembali koefisien-koefisien beta $(\boldsymbol{\beta})$ yaitu sebagai berikut:

NDAit $=\beta 1(1 /$ Ai,t-1 $)+\beta 2(\Delta$ REVt $/$ Ait-1 $-\Delta$ RECt $/$ Ait-1 $)+\beta 3($ PEt $/$ Ait-1 $)$

\section{Langkah IV}

Selanjutnya dapat dihitung nilai discretionary accruals sebagai berikut:

\section{DAit $=($ TAit/Ai,t-1 $)-$ NDAit}

Keterangan :

TACit : Total accruals perusahaan i pada periode $\mathrm{t}$

Nit : Laba bersih komprehensif perusahaan i pada periode $\mathrm{t}$

CFOit : Aliran kas aktivitas operasi perusahaan i pada periode $\mathrm{t}$

Ait-1 : Total asset perusahaan i pada periode t-1

$\Delta$ REVit : Perubahan pendapatan perusahaan i dari tahun t-1 ke tahun $\mathrm{t}$

$\Delta$ RECit : Perubahan piutang perusahaan i dari tahun $\mathrm{t}-1$ ke tahun $\mathrm{t}$

PPEit : Nilai aktiva tetap perusahaan i pada periode $\mathrm{t}$

NDAit : Non discretionary accruals perusahaan i pada periode $\mathrm{t}$

DAit : Descretionary accruals perusahaan i pada peride $\mathrm{t}$

\section{Perencanaan Pajak}

Variabel independen dalam penelitian ini adalah perencanaan pajak, perencanaan pajak diukur dengan menggunakan rumus tingkat retensi pajak (tax retention rate) yang digunakan sebegai ukuran efektivitas perencanaan pajak. Rumus tingkat retensi pajak dapat dihitung sebagai berikut:

$$
\text { TRR = } \frac{\text { Net Income }_{\text {it }}}{\text { Pretax Income EBIT }_{\text {it }}}
$$

\section{Pretax Income EBIT it $_{\text {}}$}

TRRit $=$ Tax Retention Rate perusahaan i pada tahun $\mathrm{t}$

Net Income it $=$ Laba bersih perusahaan i pada tahun $\mathrm{t}$

Pretax Income $($ EBITit $)=$ Laba sebelum pajak perusahan i pada tahun $\mathrm{t}$

\section{Beban Pajak Tangguhan}

Penghitungan tentang beban pajak tangguhan (defferent tax expense) dihitung dengan menggunakan indikator membobot beban pajak tangguhan dengan total aktiva atau total asset. Hal itu dilakukan untuk pembobotan beban pajak tangguhan dengan total asset pada periode t-1 untuk memperoleh nilai yang terhitung dengan proporsional.

\section{DTEit $=\quad$ Beban Pajak Tangguhan \\ Total asset t-1}

Keterangan ;

DTEit $=$ Defferent Tax Expense $($ beban pajak tangguhaN) perusahaan i pada tahun t.

Asset $\mathrm{t}-1=$ total aset tahun sebelumnya

\section{Kebijakan Dividen}

Kebijakan dividen merupakan keputusan atau tindakan atas laba atau keuntungan perusahaan yang diperoleh apakah akan dibagikan atau akan disimpan sebagai laba ditahan. Dalam penelitian ini kebijakan dividen yang diukur dengan dividend payout ratio (DPR) yaitu, 
rasio yang digunakan untuk mengukur besarnya pembayaran dividen dari laba per lembar saham dan mengukur besarnya laba yang ditahan untuk menambah besarnya modal sendiri (Putri, (2012: 163) dalam Wijayanti 2018). Rasio ini diukur dengan membagikan dividen perlembar saham dengan laba per lembar saham, atau diukur dengan formulasi sebagai berikut:

\section{DPR = Dividen perlembar saham \\ Laba perlembar saham}

\section{Metode Analisis Data}

Untuk menjawab permasalahan di atas, maka teknik analisis yang digunakan adalah regresi data panel, yang ditunjang dengan data kuantitatif yang ada. Data diolah dengan menggunakan software microsoft office excel 2007 dan software statistic eviews 9. Model yang digunakan dalam penelitian ini adalah sebagai berikut :

1. Statistik Deskriptif

2. Model Regresi Data Panel

a) Common Effect Model (CEM)

b) Fixed Effect Model (FEM)

c) Random Effect Model (REM)

3. Estimasi Regresi Data Panel
a) Uji Chow
b) Uji Hausman
c) Uji Lagrangage Multiplier

4. Uji Asumsi Klasik
a) Uji Normalitas
b) Uji Multikolonearitas
c) Uji Heterokedastisitas
d) Uji Autokorelasi

5. Uji Koefisien Determinasi

6. Uji Hipotesis

a) Uji F(sebagai uji simultan)

b) Uji t (sebagai uji parsial)

\section{HASIL DAN PEMBAHASAN}

Gambaran Umum Objek Penelitian

Objek penelitian ini adalah perusahaan manufaktur sektor Consumer Good Industry yang terdaftar di Bursa Efek Indonesia.

Data yang digunakan dalam penelitian ini adalah data sekunder yang bersumber dari laporan tahunan emiten dengan menggunakan populasi perusahaan manufaktur sektor industri barang konsumsi yang terdaftar di Bursa Efek Indonesia (BEI) tahun 2015-2019 dengan alamat yang diperoleh melalui situs resmi Bursa Efek Indonesia yaitu pada alamat website www.idx.co.id.

\section{Hasil Uji Statistik Deskriptif}

Uji statistik deskriptif menghasilkan deskripsi dari data yang digunakan sehingga menjadikan informasi lebih jelas dan lebih mudah untuk dipahami. Statistik deskriptif dapat dilihat dari rata-rata (mean), nilai tengah (median), nilai yang sering muncul (modus), standar deviasi, nilai maksimum dan nilai minimum(Ghozali, 2013). Hasil uji statistik deskriptif secara ringkas disajikan dalam tabel sebagai berikut: 
Tabel 2

Hasil Uji Statistik Deskriptif

Descriptive Statistics

\begin{tabular}{|l|c|c|c|c|} 
& $\mathbf{Y}$ & $\mathbf{X} 1$ & $\mathbf{X} 2$ & $\mathbf{X}$ \\
\hline Mean & 1.375883 & 0.743200 & 0.024550 & 0.374833 \\
\hline Median & 0.000000 & 0.747000 & 0.024500 & 0.335000 \\
\hline Maximum & 9.971000 & 0.934000 & 0.162000 & 1.244000 \\
\hline Minimum & -6.373000 & 0.520000 & -0.047000 & 0.000000 \\
\hline Std. Dev. & 3.755811 & 0.055654 & 0.048300 & 0.290329 \\
\hline Skewness & 0.565338 & -0.608455 & 0.843282 & 0.706891 \\
\hline Kurtosis & 2.892383 & 8.152290 & 3.712866 & 3.106191 \\
\hline & & & & \\
\hline Jarque-Bera & 3.225022 & 70.06741 & 8.381694 & 5.025145 \\
\hline Probability & 0.199386 & 0.000000 & 0.015133 & 0.081059 \\
\hline & & & & \\
\hline Sum & 82.55300 & 44.59200 & 1.473000 & 22.49000 \\
\hline Sum Sq. Dev. & 832.2607 & 0.182744 & 0.137639 & 4.973178 \\
\hline & & & & \\
\hline & 60 & 60 & 60 & 60 \\
\hline
\end{tabular}

Model Regresi Data Panel

Tabel 3

\section{Common Effect Model}

\begin{tabular}{|c|c|c|c|c|}
\hline \multicolumn{5}{|c|}{$\begin{array}{l}\text { Dependent Variable: } \mathrm{Y} \\
\text { Method: Panel Least Squares } \\
\text { Date: } 05 / 29 / 21 \text { Time: } 18: 48 \\
\text { Sample: } 2015 \text { 2019 } \\
\text { Periods included: } 5 \\
\text { Cross-sections included: } 12 \\
\text { Total panel (balanced) observations: } 60\end{array}$} \\
\hline Variable & Coefficient & Std. Error & $\mathrm{t}$-Statistic & Prob. \\
\hline $\mathrm{C}$ & 4.723649 & 6.138692 & 0.769488 & 0.4448 \\
\hline $\mathrm{X} 1$ & -6.593822 & 8.201581 & -0.803970 & 0.4248 \\
\hline $\mathrm{X} 2$ & 21.57635 & 10.27631 & 2.099620 & 0.0403 \\
\hline $\mathrm{X} 3$ & 2.729381 & 1.701611 & 1.603999 & 0.1143 \\
\hline R-squared & 0.182177 & \multicolumn{2}{|c|}{ Mean dependent var } & 1.375883 \\
\hline Adjusted R-squared & 0.138365 & \multicolumn{2}{|c|}{ S.D. dependent var } & 3.755811 \\
\hline S.E. of regression & 3.486304 & \multicolumn{2}{|c|}{ Akaike info criterion } & 5.399902 \\
\hline Sum squared resid & 680.6418 & \multicolumn{2}{|c|}{ Schwarz criterion } & 5.539525 \\
\hline Log likelihood & -157.9971 & \multicolumn{2}{|c|}{ Hannan-Ouinn criter } & 5.454516 \\
\hline F-statistic & 4.158164 & \multicolumn{2}{|c|}{ Durbin-Watson stat } & 1.879434 \\
\hline Prob(F-statistic) & 0.009929 & & & \\
\hline
\end{tabular}

Berdasarkan pengujian terhadap model regresi data panel, dapat disimpulkan bahwa hasil uji Chow, model data panel lebih baik menggunakan data panel Common Effect

\section{Uji Asumsi Klasik}

\section{Uji Normalitas}

\section{Gambar 1}

Hasil Pengujian Uji Normalitas

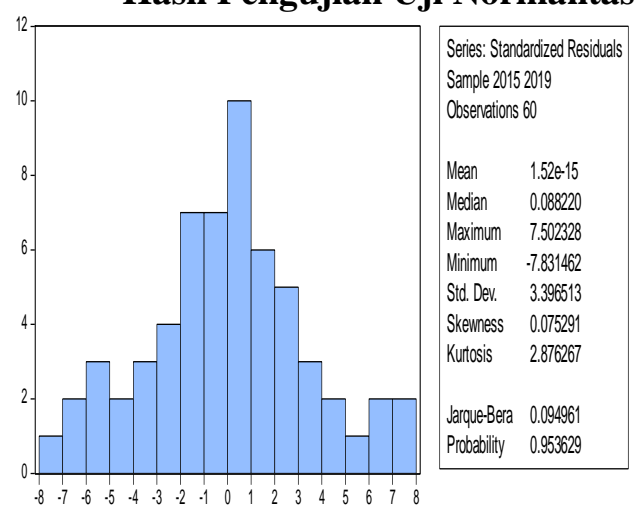

Berdasarkan hasil pengujian yang ditunjukkan pada gambar 1 diatas, diketahui bahwa probability yaitu lebih besar dari 0,05 . Hal ini sesuai dengan kriteria pengujian yang telah 
dijabarkan terlihat bahwa hasil dari uji normalitas yaitu probability sebesar 0,953629 lebih besar dari 0,05 maka dapat diambil kesimpulan bahwa data berdistribusi normal.

\section{Uji Multikolinearitas}

Tabel 4

Hasil Pengujian Uji

Multikolinearitas

\begin{tabular}{|c|c|c|c|}
\hline & X1 & X2 & X3 \\
\hline X1 & 1.000000 & -0.096507 & 0.002399 \\
\hline $\mathbf{X 2}$ & -0.096507 & 1.000000 & 0.392803 \\
\hline $\mathbf{X 3}$ & 0.002399 & 0.392803 & 1.000000 \\
\hline
\end{tabular}

Berdasarkan hasil pengujian yang ditunjukkan pada tabel 4 diketahui bahwa nilai koefisien antar variabel lebih kecil dari 0.9. Hal ini sesuai dengan kriteria pengujian bahwa hasil dari uji multikolinearitas tidak ada nilai koefisien korelasi antar variabel yang lebih dari 0.9. Maka dapat disimpulkan bahwa data tidak memiliki masalah multikolinearitas.

\section{Uji Heterokedastisitas}

Tabel 5

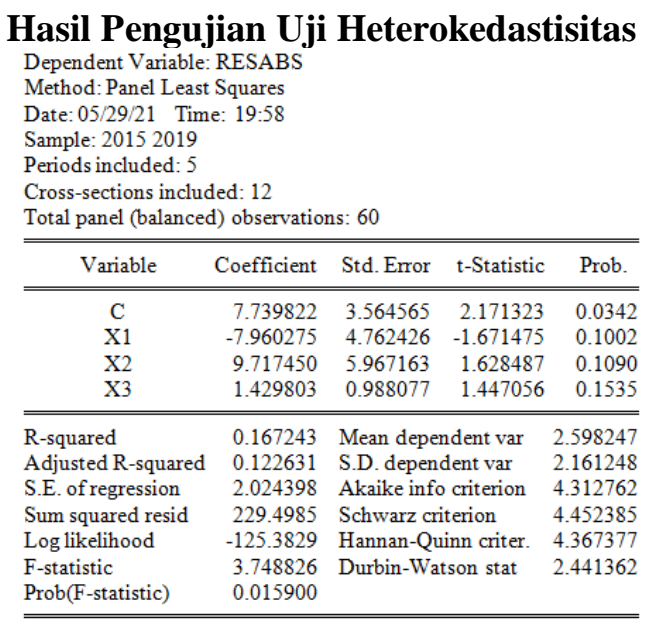

Berdasarkan hasil pengujian yang ditunjukkan oleh tabel 5 ,diketahui bahwa nilai probabilitas Obs*R-square sebesar 0,167243 .Hal ini sesuai dengan kriteria pengujian uji white bahwa hasil dari uji white memiliki nilai probabilitas Obs*R-square lebih besar daripada signifikansi $(0,167243>0,05)$. Maka dapat diambil kesimpulan bahwa data tidak memiliki masalah heteroskedasitas sebab sesuai dengan ketetapan melebihi tingkat signifikan.

\section{Uji Autokorelasi}

Tabel 6

Hasil Pengujian Uji Autokorelasi

\begin{tabular}{lr||ll}
\hline \hline Log likelihood & -157.9971 & Hannan-Quinn criter. & 5.454516 \\
F-statistic & 4.158164 & Durbin-Watson stat & 1.879434 \\
Prob(F-statistic) & 0.009929 & & \\
\hline \hline
\end{tabular}

Berdasarkan tabel 6, nilai dari statistik Durbin-Watson adalah 1,879434. Perhatikan bahwa, karena nilai statistik D-W terletak diantara 1 dan 3 yakni $1<1,879434<3$, maka asumsi non autokorelasi terpenuhi. Dengan kata lain, tidak terjadi gejala autokorelasi. 


\section{Uji Koefisien Determinasi}

Tabel 7

\begin{tabular}{lrll}
\multicolumn{4}{c}{ Hasil Uji Koefisien Determinasi } \\
\hline \hline R-squared & 0.182177 & Mean dependent var & 1.375883 \\
Adjusted R-squared & 0.138365 & S.D. dependent var & 3.755811 \\
S.E. of regression & 3.486304 & Akaike info criterion & 5.399902 \\
Sum squared resid & 680.6418 & Schwarz criterion & 5.539525 \\
Log likelihood & -157.9971 & Hannan-Quinn criter. & 5.454516 \\
F-statistic & 4.158164 & Durbin-Watson stat & 1.879434 \\
Prob(F-statistic) & 0.009929 & & \\
\hline \hline
\end{tabular}

Berdasarkan tabel 7 besarnya adjusted R- squared sebesar 0,138365 menandakan bahwa variasi manajemen laba mampu dijelaskan secara serentak atau dipengaruhi oleh variabel dalam penelitian ini sebesar $13 \%$ sedangkan sisanya $87 \%$ dijelaskan oleh faktor lain yang tidak dimasukkan ke dalam penelitian ini.

\section{Uji Hipotesis \\ Uji F (sebagai uji simultan)}

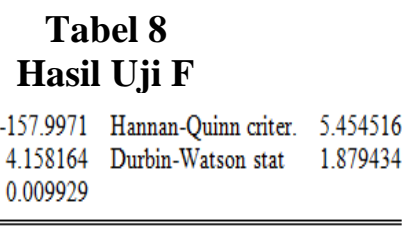

Dari hasil uji F pada tabel 8, diketahui bahwa nilai probabilitas (Prob) ( F- Sstatistic sebesar $0,009929<$ dari $\alpha(0,05) \mathrm{Maka}_{0} \mathrm{H}_{0}$ ditolak sehingga model regresi yang diestimasi layak digunakan untuk menjelaskan pengaruh perencanaan pajak, beban pajak tangguhan dan kebijakan dividen terhadap manajemen laba.

\section{Uji t (sebagai uji parsial)}

Tabel 9

\begin{tabular}{ccccc} 
& \multicolumn{2}{c}{ Hasil Uji t } & & \\
Variable & Coefficient & Std. Eror & t-Statistic & Prob. \\
\hline \hline $\mathrm{C}$ & 4.723649 & 6.138692 & 0.769488 & 0.4448 \\
$\mathrm{X} 1$ & -6.593822 & 8.201581 & -0.803970 & 0.4248 \\
$\mathrm{X} 2$ & 21.57635 & 10.27631 & 2.099620 & 0.0403 \\
$\mathrm{X} 3$ & 2.729381 & 1.701611 & 1.603999 & 0.1143 \\
\hline \hline
\end{tabular}

Berdasarkan tabel 9 diatas dapat diinterpretasikan pengaruh variabel independen terhadap variabel dependen sebagai berikut :

1. Variabel perencanaan pajak (X1) memiliki nilai t-statistic sebesar $-0,803970$ dengan nilai probabilitas sebesar $0,4248>$ dari tingkat signifikansi $(0,05)$, sehingga dapat disimpulkan bahwa perencanaan pajak tidak berpengaruh negatif terhadap manajemen laba.

2. Variabel beban pajak tangguhan (X2) memiliki nilai t-statistic sebesar 2,099620 dengan nilai probabilitas sebesar 0,0403 < dari tingkat signifikansi $(0,05)$, sehingga dapat disimpulkan bahwa variabel beban pajak tangguhan berpengaruh positif terhadap manajemen laba.

3. Variabel kebijakan dividen (X3) memiliki niali t-statistic sebesar 1,603999 dengan nilai pobabilitas sebesar 0,1143 > dari tingkat signifkansi $(0,05)$, sehingga dapat disimpulkan bahwa variabel kebijakan dividen tidak berpengaruh positif terhadap manajemen laba. 


\section{SIMPULAN}

1. Hasil penelitian ini menunjukkan bahwa perencanaan pajak tidak berpengaruh terhadap manajemen laba pada perusahaan manufaktur sektor consumer good industry yang terdaftar di Bursa Efek Indonesia periode 2015-2019.

2. Hasil penelitian ini menunjukkan bahwa beban pajak tangguhan berpengaruh terhadap manajemen laba pada perusahaan manufaktur sektor consumer good industry yang terdaftar di Bursa Efek Indonesia periode 2015-2019.

3. Hasil penelitian ini menunjukkan bahwa kebijakan dividen tidak berpengaruh terhadap manajemen laba pada perusahaan manufaktur sektor consumer good industry yang terdaftar di Bursa Efek Indonesia periode 2015-2019.

4. Hasil penelitian ini menunjukkan bahwa perencanaan pajak, beban pajak tangguhan dan kebijakan dividen berpengaruh secara simultan terhadap manajemen laba pada perusahaan manufaktur sektor consumer good industry yang terdaftar di Bursa Efek Indonesia periode 2015-2019.

\section{SARAN}

1. Penelitian ini dapat diperluas dan diperdalam dengan cara menambahkan variabelvariabel independen yang diduga berpengaruh kuat dalam mendeteksi manajemen laba.

2. Diharapkan memperluas atau menambah sampel seperti perusahaan non-manufaktur yang terdaftar di Bursa Efek Indonesia, sehingga tidak hanya meneliti pada perusahaan manufaktur saja.

\section{Keterbatasan}

1. Variabel independen dalam penelitian ini menjelaskan variabel dependen (manajemen laba) rendah dilihat dari nilai adjusted $\mathrm{R}$ Square yang rendah pada penelitian ini yaitu 0,138365 atau $13 \%$ yang artinya $87 \%$ dari $100 \%$ yang ada, variabel independen dijelaskan diluar penelitian ini.

\section{DAFTAR PUSTAKA}

Achyani, F., \& Lestari, S. (2019). Pengaruh Perencanaan Pajak Terhadap Manajemen Laba. Jurnal Riset Akuntansi dan Keuangan Indonesia , 84

Ghozali, I. (2005). Aplikasi Analisis Multivariate dengan SPSS. Semarang: Badan Penerbit UNDIP.

Lestari, F. A. (2018). Pengaruh Profitabilitas dan Beban Pajak Tangguhan Terhadap Manajemen Laba. 277.

Lubis, I., \& Suryani. (2018). Pengaruh Tax Planning, Beban Pajak Tangguhan dan Nilai Perusahaan Terhadap Manajemen Laba (Studi Empiris pada Perusahaan Industri Barang Konsumsi di Bursa Efek Indonesia Tahun 2012 - 2016). Jurnal Akuntansi dan Keuangan, 42.

Putra, R. H., Sunarta, K., \& Fadhillah, H. (2019). Pengaruh Perencanaan Pajak dan Beban Pajak Tangguhan Terhadap Manajemen Laba Pada Perusahaan Manufaktur Sub Sektor Makanan dan Minuman Yang Terdaftar di Bursa Efek Indonesia Periode 2013 - 2017.

Suripto. (2021). Pengaruh Corporate Social Responsbility, Kualitas Audit Dan Manajemen Laba Terhadap Tax Avoidance Pada Perusahaan Pertambangan Yang Terdaftar Di Bursa Efek Indonesia. Jurnal Ilmiah Manajemen, Ekonomi dan Akuntansi , 1651 - 1672.

Timuriana, T., \& Muhammad, R. R. (2015). Pengaruh Aset Pajak Tangguhan dan Beban Pajak Tangguhan Terhadap Manajemen Laba. Jurnal Ilmiah Akuntansi Fakultas Ekonomi, 12-20.

Wijayanti, P. R. (2018). Pengaruh Mekanisme Good Corporate Governance, Kebijakan Dividen, Dan Profitabilitas Terhadap Manajemen Laba. Jurnal Ilmu dan Riset Akuntansi , 6. 
Wirawati, N. G., Putri, I. G., \& Wirasedana, I. W. (2018). Pengaruh Kebijakan Dividen, Kompensasi, dan Leverage Pada Manajemen Laba di Perusahaan Manufaktur. Jurnal Kumpulan Riset Akuntansi , 38. 